\title{
Methodology of risk assessment for electricity distribution lines in Slovakia with regard to potential bird mortality due to collisions with power lines
}

\author{
Metodika hodnotenia rizikovosti elektrických vedení na Slovensku z pohl'adu možného \\ úhynu vtákov spôsobeného nárazom do vedenia
}

\author{
Ján ŠMíDT, Ervín HAPL \& Marek GÁLIS
}

\begin{abstract}
Power lines represent an important and increasing worldwide cause of avian mortality due to collisions involving flying birds. One positive and very important fact is that only some parts of potentially dangerous lines are responsible for the majority of killed birds. These sections need to be identified and treated with proper mitigation measures. In this article we present a specially-prepared methodology aimed at classifying power lines according to the risk they present. The identification of power lines with the highest risk of possible bird collision requires easily-accessed biological, technical and landscape information. In addition to analyses of these main inputs, our methodology also evaluates the influence of power line orientation relative to the important migration routes of birds, the effect of nearby tree growth higher than the evaluated power lines, and the complexity of landscape relief. Based on these three additional inputs, it is possible to produce a digitalized map showing with onemeter accuracy the location of power line sections with the high/middle/low mortality risk due to collision for any existing or newly-planned grid. Sections with highest risk should be considered as priority for the implementation of mitigation measures including e.g. installation of bird flight diverters. Our methodology was prepared for $22 \mathrm{kV}$ and $110 \mathrm{kV}$ distribution power lines in Slovakia. It is flexible enough to be applied equally to any geographic conditions and/or bird community, different voltage levels and construction designs of power lines. Our methodology can be applied by ornithologists, nature conservancy organization and power line system operators to implement environmental and cost-effective mitigation measures.
\end{abstract}

\begin{abstract}
Abstrakt: Elektrické vedenie predstavujú v celosvetovom meradle významnú a narastajúcu príčinu mortality vtákov v dôsledku nárazov. Pozitívny a vel'mi dôležitý fakt je, že za väčšinu usmrtených vtákov sú zodpovedné iba najrizikovejšie úseky vedení. Tie je potrebné správne identifikovat' a ekologizovat' vhodnými opatreniami. V článku predstavujeme špeciálne vytvorenú metodiku zameranú na klasifikáciu elektrického vedenia podl’a rizika, ktoré predstavuje. Identifikácia úsekov s najvyšším rizikom nárazov vtákov si vyžaduje pomerne l’ahko dostupné vstupné biologické, technické a topografické informácie. Okrem analýz týchto hlavných vstupov naša metodika hodnotí aj vplyv orientácie elektrického vedenia vo vzt’ahu $\mathrm{k}$ dôležitým migračným trasám vtákov, vplyv blízkeho stromového porastu vyššieho ako hodnotené elektrické vedenie a členitost' reliéfu krajiny. Na základe týchto troch d’alších vstupov je možné pre existujúcu alebo novo plánovanú siet' vytvorit' digitalizovanú mapu ukazujúcu polohu úsekov elektrického vedenia s vysokým/stredným/nízkym rizikom s presnost’ou na jeden meter. Úseky s najvyšším rizikom, je potrebné považovat' za prioritné pri následnej implementácii prijatých opatrení akými sú napr. inštalácia odkloňovacích prvkov. Metodika bola pripravená pre distribučné vedenia $22 \mathrm{kV}$ a $110 \mathrm{kV}$ na Slovensku, je však dostatočne flexibilná, aby sa dala aplikovat' aj na iné geografické podmienky a/alebo iné ornitocenózy a rôzne napätové úrovne a konštrukcie elektrických vedení. Metodika môže byt' využitá pre potreby ornitológov, orgánov ochrany prírody a prevádzkovatel'ov elektrických vedení tak, aby boli prijaté ekologicky účinné a cenovo efektívne opatrenia.
\end{abstract}

Key words: collision risk, bird mortality, impact assessment, power lines

Ján Šmídt, Ervín Hapl, Marek Gális*, Raptor Protection of Slovakia, Trhová 54, SK-841 01 Bratislava, Slovakia. *E-mail: galis@dravce.sk.

Acknowledgements: This methodology was developed as part of the project named LIFE13 NAT/SK/001272 Energy in the Land - power lines and conservation of priority bird species in the Natura 2000 sites (www.lifeenergia.sk), supported by the European Union within the LIFE programme and by the Ministry of Environment of the Slovak Republic. We would also like to thank all the field assistants who have contributed to improving the settings of the monitored factors and subsequent fine-tuning of the processing methods for data acquired from field monitoring of $22 \mathrm{kV}$ and $110 \mathrm{kV}$ power lines between $12 / 2014$ and $02 / 2016$. We wish to thank anonymous reviewers and the executive editor for the valuable comments on the text. 
Šmídt J, Hapl E \& Gális M: Methodology of risk assessment for electricity distribution lines in Slovakia with regard to potential bird mortality due to collisions with power lines

\section{Introduction}

Birds have to adapt themselves constantly to anthropogenic changes in the countryside. These happen too quickly, however, for adequate genetic adaptation to develop in the bird population. Not only do people transform their natural environment in radical ways, they also put up many kinds of artificial barriers in the land such as electric power lines. The growing numbers of observed interactions between birds and power lines is linked with the worldwide increase in extent of such lines, which was estimated in 2010 at more than 65 million kilometers of transmission and distribution lines (Jenkins et al. 2010). Collisions with power lines are a studied and confirmed cause of bird mortality in many countries of the world (Alonso \& Alonso 1999, Rubolini et al. 2005, Derouaux et al. 2012, Gális et al. 2016, Bernardino et al. 2018) and may have fundamental negative impact on endangered and reduced populations on the local level (Crowder 2000, Drewitt \& Langston 2008, Shaw et al. 2010, Raab et al. 2012). It is possible to observe collisions most frequently in areas where the power lines cross the hunting and nesting biotopes used by large bird populations (Andriushchenko \& Popenko 2012). Even if the power lines are just in the vicinity of those areas, there is still high probability of numerous collisions (Erickson et al. 2005), especially near places used for taking off and landing (Heck 2007, Quinn et al. 2011). A particular problem arises when there are frequent movements of large flocks between their hunting and nesting biotopes, or if the power lines pass perpendicularly across the birds' main migration routes (Crowder 2000, Shobrak 2012).

In order to apply effective protection measures, it is necessary to know to what degree a certain power line is "problematic" for birds. It is important to precisely establish the extent to which the protection measures need to be applied, so that only the sections of power line representing the greatest risk are targeted, i.e. where the probability of bird mortality is highest.

According to current scientific knowledge and published studies, the principal causes making up the set determining the degree of risk are divided into three categories (Bernardino et al. 2018). These consist of the environmental conditions of the site, the morphology/ ecology of the bird species and the technical parameters of the power line. The individual factors are closely interlinked, and they participate together with various weightings in the resulting degree of risk associated with collisions.
From the biological point of view the group most susceptible to collisions and therefore at greatest risk are the large, heavy bird species (Janss 2000, Janss \& Ferrer 2000, Rubolini et al. 2005, APLIC 2012, Barrientos et al. 2012) and certain specific orders of birds, e.g. Anseriformes, Ciconiiformes, Gaviiformes and Pelecaniformes (Bevanger 1998), defined according to their morphological parameters (e.g. weight, wing size/ area, manner/type of flight). The species which tend to group together into large flocks are also included here, as they are associated with higher probability of collision (APLIC 1994, Drewitt \& Langston 2008, APLIC 2012).

The environmental conditions of the site influencing the resulting degree of risk of collision are above all the character and composition of the landscape. Open, flat land with low vegetation enables birds to fly low and close to the terrain, seeking out sources of food and resting places. As a result, they may tend to have reduced levels of concentration on potential obstacles such as electric power lines. Birds have a general tendency to look downwards, and thus for certain species the space ahead of them becomes a so-called blind zone (Martin \& Shaw 2010, Martin 2011). Tall tree growth in the vicinity of power lines may alert such birds to the potential obstacle, but only if the trees reach up above the highest part of the power line (Bevanger \& Brøseth 2004, APLIC 2012). The principal technical parameters affecting the degree of risk represented by a power line are the thickness of the cables, the height of the line and the number of parallel lines. Higher lines increase the risk of collision (APLIC 1994, Haas et al. 2005). Not only do the birds have to overcome a higher barrier, but relatively often they then collide with the earth wire which is present at the top of higher-tension distribution and transmission lines to protect them from lightning strikes, and at the same time is much thinner than the live cables. This is connected with the fact that birds try to avoid power lines primarily by flying over them (Murphy et al. 2009), so they react to the visibly thicker live cables but then fly into the practically "invisible" earth wire above them. Denser networks of parallel power lines are more visible to birds, so they manage to react to the obstacle earlier (Bevanger 1994, Crowder 2000, Drewitt \& Langston 2008), and they can usually fly over sets of parallel lines with a single soar.

In identifying the causes of collisions and establishing the degree of risk represented by power lines, it is important to start out from the above-mentioned catego- 
ries of factors. They should be applied as input variables in any method of assessing the degree of risk in power lines with regard to collisions. Various categorizations of power lines into groups with similar degrees of risk and designations of priority areas can be found in a range of foreign studies, for example from Belgium (Derouaux et al. 2012), Portugal (Silva et al. 2014), Portugal and Spain (D'Amico et al. 2019), the USA (Heck 2007, Quinn et al. 2011) or South Africa (Shaw et al. 2010).

We set out from the same categories of input variables in our methodology too, which was developed as part of the LIFE Energy project. It was based on a systematic approach to resolving the problems of bird collisions with power lines, involving proposals of suitable ways of identifying and eliminating this kind of risk in 13 Special Protection Areas (SPAs) in Slovakia. This methodology was developed for the purposes of primary identification of risky sections of power lines, so that the protection measures subsequently applied could be focused solely on those sections representing the greatest risk where there is a high probability of bird collisions. In addition to the basic procedures as used in other methodologies (i.e. identifying relative locations of power lines vs. sites with concentrated bird population vs. migration routes, for instance), in the methodology presented here we also calculate in the influence of power line orientation relative to the presumed prevailing direction of bird movement, the influence of the slope of the terrain, and the influence of tree growth present near the power lines. These three additionally assessed input variables have the effect of significantly reducing the resulting length of line sections which are evaluated as risky, since the real degree of risk is reduced or even eliminated by them. In creating our methodology we made use of the available foreign literature, especially the documents APLIC (1994) and APLIC (2012). The presented methodology also reflects the current state of knowledge and experience among members of the project team from Raptor Protection of Slovakia with regard to issues of bird collisions with power lines in this country, acquired during monitoring of 22 $\mathrm{kV}$ and $110 \mathrm{kV}$ distribution lines in the period 12/2014 to $02 / 2016$, and also makes use of insights derived from previous practice going back to 2010. An evaluation of risk levels on $6,235 \mathrm{~km}$ of $22 \mathrm{kV}$ and $110 \mathrm{kV}$ power lines within Slovakia was presented in the work by Šmídt et al. (2017). According to that methodology it is possible to divide lines into three categories of degree of risk and need for application of suitable protection mea- sures. Apart from its application on existing lines, it is also possible to apply this methodology to the identification of potential risky sections during the design phase for new distribution and transmission lines. On the basis of these recommendations it is possible to change the routing of lines, or plan in advance for the measures required and include the financial costs incurred into the project documentation.

This assessment methodology was developed for the bird species and types of power lines present in Slovakia. It is flexible enough however to be potentially adapted for other geographical conditions, or for different ornithocenoses and other power line tension ratings and construction designs. In this article we present only the methodology of the assessment procedure, and we do not deal with the correlation of bird mortality recorded during monitoring with the evaluated sections of lines with low, medium and high degrees of risk.

\section{Material and methods}

The procedure itself of categorizing degrees of risk on power lines is composed of several interlinked logical steps. These involve identifying the ornithofauna, the type and composition of the landscape structure, and the technical parameters of the power line in the area in question.

The most suitable tool for assessing power line risk levels in our view is a digital model of the particular area being studied created in the geographical information system (GIS) environment. This digital model consists of individual geographical digital sources, either vector or raster layers.

The input data are made up of the following sources:

- an orthophotomap of the assessed area* (in the visible spectrum); ideally we work with at least two orthophotomaps of the assessed area taken at different times (at least one year apart), and a standard $1: 10,000$ scale map may be of supplementary assistance,

- a satellite image in the infrared spectrum,

- a layer or point array* of key sites where regular concentrations of the indicated bird species occur (this applies only when such sites exist in the assessed area),

- a flood map of the area*; it is also possible to use a geological map (floodplains) or a digital relief

* Obligatory sources without which the model would be incomplete; if any of the sources are not available, a relevant alternative must be obtained. 
Šmídt J, Hapl E \& Gális M: Methodology of risk assessment for electricity distribution lines in Slovakia with regard to potential bird mortality due to collisions with power lines

model, or floodplains may be identified from the contours on the standard 1:10,000 scale map,

- a map of the geomorphological composition of the area*,

- a relief map showing slope distribution*; alternatively a digital relief model or a map showing valuations of agri-ecological units (BPEJ). If the latter is used, the slope in the relief is given in each BPEJ code, namely in the fifth digit of the sevenplace code,

- a layer of vegetation features reaching higher than the power line in question: this may be created based on the orthophotomap supplemented with data from practical investigation of the terrain; for wooded areas in particular it is possible to use a map showing tree cover,

- a layer of power lines*; this layer must contain data on the tension rating of the line, the number of horizontal cable-bearing crossbars, and cable thickness.

\section{Calculation of power line risk level}

For assessing the degree of risk on a section of power line with regard to bird collisions, we applied the following equation:

$$
R=K \times L \times P
$$

where: $R=$ degree of risk of bird collision on the section of power line, $K=$ criterion of "key site", quantifying the attractivity of the locality for birds, $L=$ criterion of "landscape elements", quantifying their influence on the degree of risk, $P=$ criterion of "power line", quantifying the influence of power line features on the degree of risk.

The calculated values for criterion $K$ range from 0 100 , and are subsequently confirmed or reduced by the values for criterion $L(0-1)$ and criterion $P(0-1)$.

The result of this assessment is that sections of power line can be categorized on three levels based on the $R$ values reached (Fig. 1):

- values between 75-100 indicate sections with high risk of collision,

- values between 50-75 indicate sections with medium risk of collision,

- values between 0-50 indicate sections with low/negligible risk of collision.

Assessment is done based on the overlap of power lines with buffer zones. For $22 \mathrm{kV}$ lines the buffer zones are set at distances of $80 \mathrm{~m}, 160 \mathrm{~m}$ and $240 \mathrm{~m}$, and for $110 \mathrm{kV}$ they are set at distances depending on the vicin- ity of key or potential key sites. In this way it is possible to determine precisely (with one-metre accuracy in the GIS environment) the extent of influence of a power line.

\section{K e y $\mathrm{sites}(\mathrm{c} r$ i t e rion $K$ )}

This criterion takes into account the presence of sites which are attractive for susceptible bird species in the relevant vicinity of the assessed section of power line,

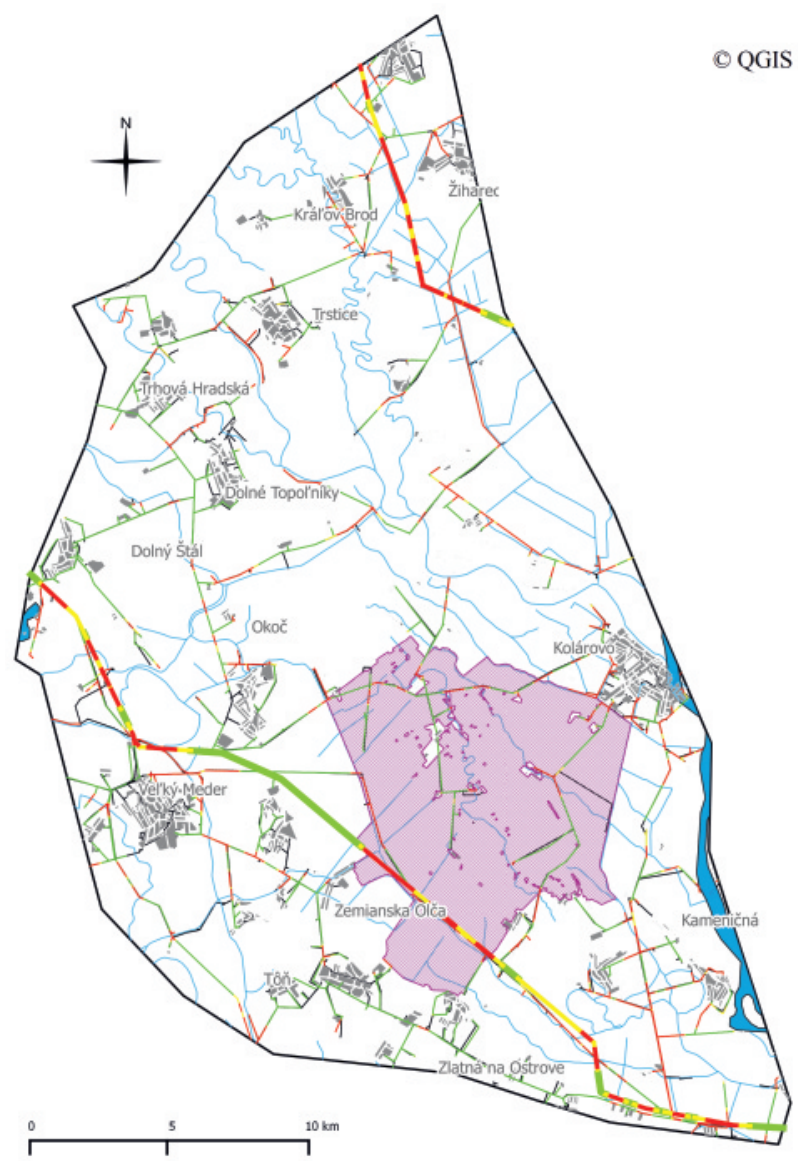

$$
\begin{aligned}
& 22 \mathrm{kV} \text { power line/vedenie } 22 \mathrm{kV} \\
& \text { — low risk of collision'nizke riziko nárazu (0-50) } \\
& \text { medium risk of collision/stredné riziko nárazu (50-75) } \\
& \text { - high risk of collision/vysoké riziko nárazu (75-100) } \\
& 110 \mathrm{kV} \text { power line/vedenie } 110 \mathrm{kV} \\
& \text { - low risk of collision/nizke riziko nárazu (0-50) } \\
& \text { medium risk of collision/stredné riziko nárazu (50-75) } \\
& \text { high risk of collision/vysoké riziko nárazu (75-100) } \\
& \text { SPA/CHVÚ }
\end{aligned}
$$

Fig. 1. Example of resulting visualization of categorization of 22 $\mathrm{kV}$ and $110 \mathrm{kV}$ power lines with regard to degree of risk of collisions.

Obr. 1. Príklad výslednej vizualizácie zatriedenia vedení $22 \mathrm{kV}$ a 110 kV do kategórií rizikovosti. 
and its weight depends on the real or potential numbers of birds. For each power line section assessed the higher of the two subcriterion values $K_{1}$ and $K_{2}$ is used.

$$
K=\max \cdot\left(K_{1}, K_{2}\right)
$$

The factors in the two subcriteria are quantified in such a way that the values of criterion $K$ for any given power line section (or for any given point in the landscape) range between 0 and 100 .

\section{K n ow n k e y s i t e s $\left(K_{l}\right)$}

An evaluation of the current known status of populations of indicated bird species at key sites in the relevant vicinity of a power line (for $22 \mathrm{kV}$ lines up to a distance of $240 \mathrm{~m}$ from the edge of the site, and for $110 \mathrm{kV}$ lines up to a distance of $600 \mathrm{~m}$ from the edge of the site). We consider a site as key when a concentration of a large number of birds from a susceptible (indicated) species occurs there, i.e. it is that species' regular (annual) nesting, roosting or gathering site, a place for resting or gathering food. We consider a bird species as susceptible (indicated) when individuals are relatively often killed as a result of colliding with power lines, i.e. their cadavers indicate relatively higher frequency of collision on specific sections of power line. With regard to possible differentiation in the species' composition and the occurrence of similar species in other regions, it is necessary also to take into account data on related species which may appear to be susceptible (indicated) in other regions as well. This mainly concerns taxonomic groups selected in line with the categorization according to Bevanger (1998), e.g. Anseriformes, Ciconiiformes, Gaviiformes, Gruiiformes and Pelecaniformes. These are orders comprising species of large, heavy birds with a high ratio of body weight to wing area and limited manoeuvrability (Janss 2000), as well as species which tend to congregate in large flocks (APLIC 2012) and have poor periferal vision (Martin 2011).

Based on the categorization of species according to their morphological and behavioural parameters indicating higher risk of collision, and also on our previous observations in the field, it was possible to specify the following species as susceptible (indicated) in the conditions of Slovakia: mute swan Cygnus olor, grey heron Ardea cinerea, black-crowned night heron Nycticorax nycticorax, great egret Ardea alba and mallard Anas platyrhynchos.

The value of subcriterion $K_{l}$ is calculated using the equation:

$$
K_{1}=k_{1 a} \times k_{l b}
$$

where: $K_{1}=$ subcriterion of known key site, quantifying the real (current) attractivity level for birds, $k_{l a}=$ factor of size of population of indicated bird species, $k_{l b}=$ factor of power line distance from the key site.

The real attractivity level of the site is indicated by the size of population of the indicated bird species (Tab. 1) regularly making use of the particular site. Factor $k_{l a}$ expresses the real attractivity level of the site and of individual buffer zones in the vicinity affected by factor $k_{1 b}$ (Tabs. 2 and 3) for the indicated species (i.e. distances up to 80,160 and $240 \mathrm{~m}$ from the edge of the site for $22 \mathrm{kV}$ lines up to 200,400 and $600 \mathrm{~m}$ from the edge of the site for $110 \mathrm{kV}$ lines), whereby the combined total of numbers in their local populations is applied.

Factor $k_{l b}$ reflects the assumption that the degree of risk of bird collision with power lines is reduced with increasing distance from the key site. As a result of the

Tab.1. Values of factor $k_{1 a}$ depending on the population size of indicated species.

Tab. 1. Hodnoty faktora $k_{1 a} v$ závislosti od početnosti populácií indikačných druhov.

\begin{tabular}{cc}
\hline population size of indicated species / početnost' populácií indikačných druhov & value of factor $\boldsymbol{k}_{1 a} /$ hodnota faktora $\boldsymbol{k}_{1 a}$ \\
\hline 5100 individuals / jedincov & 100 \\
$51-100$ individuals / jedincov & 75 \\
$20-50$ individuals / jedincov & 50 \\
$<20$ individuals / jedincov & 0 \\
\hline
\end{tabular}

Tab. 2. Values of factor $k_{1 b}\left(k_{2 b}\right)$ for $22 \mathrm{kV}$ lines.

Tab. 2. Hodnoty faktora $k_{1 b}\left(k_{2 b}\right)$ pre $22 \mathrm{kV}$ vedenia.

\begin{tabular}{cc}
\hline distance from real (potential) key site $/$ & value of factor $\boldsymbol{k}_{1 b}\left(\boldsymbol{k}_{2 b}\right) /$ \\
vzdialenost' od reálnej (potenciálnej) významnej lokality & 1 \\
\hline$<80 \mathrm{~m}$ & 0.67 \\
$81-160 \mathrm{~m}$ & 0.33 \\
$161-240 \mathrm{~m}$ & 0 \\
\hline $240 \mathrm{~m}$ & $\left.\boldsymbol{k}_{\mathbf{1 b}}\right)$ \\
\hline
\end{tabular}


Šmídt J, Hapl E \& Gális M: Methodology of risk assessment for electricity distribution lines in Slovakia with regard to potential bird mortality due to collisions with power lines

dispersal of birds in various directions from the site, with increasing distance there is most likely a drop in frequency of their occurrence at any given point. At the same time with increasing distance the flying height of the individual above the ground also increases, and so similarly with increasing distance the probability of hitting a power line is reduced. If we presume the same angle of climb for individuals from the site, then the higher $110 \mathrm{kV}$ lines represent greater probability of collision at the same distance compared with the lower 22 $\mathrm{kV}$ lines.

\section{$\mathrm{P}$ o t e n t i a 1 k e y $\mathrm{sites}\left(K_{2}\right)$}

These are defined as sites which are potentially attractive for an indicated species, where concentrations of large numbers of individuals of that species may be expected in the future, for example after floods or a change in the ecological conditions in a geographically close key site.

The value of subcriterion $K_{2}$ is calculated using the equation:

$$
K_{2}=k_{2 a} \times k_{2 b} \times k_{2 c}
$$

where: $K_{2}=$ subcriterion of potential key site, quantifying the site's potential attractivity level for birds, $k_{2 a}$ $=$ factor of character of the potential key site, $k_{2 b}=$ factor of power line distance from the potential key site, $k_{2 c}=$ geographical factor accounting for differing quality of biotopes and migration routes of birds in a wider context.

The factor of character of a potential key site $k_{2 a}$ quantifies the otherwise qualitative characteristics of particular landscape features with values ranging from
25 to 50 (Tab. 4). In this case the feature is a flood area, either the floodplain of a river/stream or some wetlands, a water body, marsh, water course including oxbow lakes, or an occasionally flooded depression in the terrain. The selection of these features is based on our local (regional) knowledge and the availability of data on numbers of birds in the given region. This means that in decision-making on taking a specific landscape element into account, it is not just the size of that element or the width of the watercourse which is important, but also the species composition and size of the bird population in the region. We do not take into consideration landscape elements in a region which do not have the potential to concentrate more than twenty individuals of an indicated species. The selection may be based on the results of ornothological census.

Identification of potential key sites is one of the more time-consuming operations in the assessment process. Water bodies and marshes can be found on standard 1:10,000 scale maps, but these do not enable identification of occasionally flooded depressions in arable or grass land. These have to be found using orthophotomaps from at least two different time periods, which can then be compared. Should the source maps not be up to date, we recommend combining the available graphic material with physical investigation of such sites. Factor $k_{2 b}$ is similar to factor $k_{1 b}$ in that it also expresses the declining level of risk of collisions with power lines as the distance from the potential key site increases. Values of factor $k_{2 b}$ are given in tables 2 and 3 together with those for factor $k_{l b}$.

Factor $k_{2 c}$ is a geographical factor taking into account the differing quality of biotops and landscapes as well as the migratory routes of birds. Values for factor

Tab. 3. Values of factor $k_{1 b}\left(k_{2 b}\right)$ for $110 \mathrm{kV}$ lines.

Tab. 3. Hodnoty faktora $k_{1 b}\left(k_{2 b}\right)$ pre $110 \mathrm{kV}$ vedenia.

\begin{tabular}{cc}
\hline distance from real (potential) key site $/$ & value of factor $\boldsymbol{k}_{1 b}\left(\boldsymbol{k}_{2 b}\right) /$ \\
vzdialenost' od reálnej (potenciálnej) významnej lokality & hodnota faktora $\boldsymbol{k}_{\mathbf{1 b}}\left(\boldsymbol{k}_{\mathbf{2 b}}\right)$ \\
\hline$<200 \mathrm{~m}$ & 0.8 \\
$201-400 \mathrm{~m}$ & 0.6 \\
$401-600 \mathrm{~m}$ & 0 \\
\hline$>600 \mathrm{~m}$ & 0 \\
\hline
\end{tabular}

Tab. 4. Values of factor $k_{2 a}$ for landscape elements which may be potential key sites.

Tab. 4. Hodnoty faktora $k_{2 a}$ pre krajinné prvky, ktoré môžu byt' potenciálnou významnou lokalitou.

\begin{tabular}{cc}
\hline character of the landscape element / charakter krajinného prvku & value of factor $\boldsymbol{k}_{\mathbf{2 a}} /$ hodnota faktora $\boldsymbol{k}_{\mathbf{2 a}}$ \\
\hline water body / vodná plocha & 50 \\
watercourse or oxbow lake / vodný tok, napájadlo & 50 \\
marsh / mokrad' & 50 \\
flooded depression in terrain / zaplavená pol'ná depresia & 50 \\
area liable to flooding / záplavové územie & 25 \\
\hline
\end{tabular}






Fig. 2. Example of the differentiation of the territory of Slovakia based on values of factor $k_{2 c}$.

Obr. 2. Príklad rozdelenia územia Slovenska s hodnotami faktora $k_{2 c}$.

$k_{2 c}$ may range from 1.2 in geomorphological areas which are unsuitable for the indicated species (e.g. highlands) and 1.8 for basins and hill ranges up to the highest value 2.0 in geomorphological areas (lowlands) with optimal biotopes for the indicated species. We can use the territory of the Slovak Republic as an example, which can be differentiated into five categories and for each one the value of factor $k_{2 c}$ can be assigned. The resulting topographical map is shown in Fig. 2.

In the GIS environment all the key and potential key sites have zones (buffers) created around them reaching the distances shown in Tab. 2 and Tab. 3 for the assessment of $22 \mathrm{kV}$ and $110 \mathrm{kV}$ power lines. The values of factors $k_{2 a}$ and $k_{2 b}$ are determined for the individual buffer zones in the sense that the factor values decrease for the zones which are further away from the site. For the key and potential key sites themselves the factor value is set at 1.0. To save work, for the purposes of vectorizing (creating digital maps) it is possible to ignore sites further than $240 \mathrm{~m}$ from assessed sections of $22 \mathrm{kV}$ lines and sites further than $600 \mathrm{~m}$ from assessed sections of $110 \mathrm{kV}$ lines. The reason is that the digital model does not show concentrations of birds at more distant sites as incurring any risk of collision with power lines which are sufficiently far away.
L a n d s c a p a n d lands cape e 1 ements (criterion $L-1$ and$\mathrm{s}$ c a p e )

The value of criterion $L$ is calculated as the product of two landscape factors which we monitor in assessing the degree of risk on sections of power line:

$$
L=l_{1} \times l_{2}
$$

where: $L=$ criterion of landscape elements, quantifying the influence of such elements on the power line risk level, $l_{1}=$ factor of slope in relief, $l_{2}=$ factor of proximity of tall tree growth.

Values of criterion $L$ range between 0 and 1 .

S lop e in re li e f

The basis for obtaining data on slopes in relief may be a digital relief model, or a relief map showing slopes in degrees may be produced in the GIS raster environment. In both cases slopes are divided into three classes 0 to $3^{\circ}, 3$ to $7^{\circ}$ and more than $7^{\circ}$, and the corresponding value of factor 11 is taken from Tab. 5 .

Tab. 5. Values of factor $I_{1}$ for increasing slopes in relief.

Tab. 5. Hodnoty faktora $I_{1} v$ závislosti od sklonu reliéfu.

\begin{tabular}{cc}
\hline slope in relief $/$ sklon reliéfu & value of factor $I_{1} /$ hodnota faktora $I_{1}$ \\
\hline $0-3^{\circ}$ & 1.0 \\
$3-7^{\circ}$ & 0.3 \\
$>7^{\circ}$ & 0.0 \\
\hline
\end{tabular}


Šmídt J, Hapl E \& Gális M: Methodology of risk assessment for electricity distribution lines in Slovakia with regard to potential bird mortality due to collisions with power lines

Vegetation i n proxim ity of $\mathrm{p}$ o w e r $1 \mathrm{in}$ e $\mathrm{s}$

As in the case of identifying potential key sites using orthophotomaps, finding vegetation features taller than the nearest power line can also be quite time-consuming. This can also be done by reading from orthophotomaps. The height of tree growth in particular can be estimated based on the structure and length of shadow of vegetation features studied on the orthophotomap, or it can be determined directly by means of personal field study. It is not possible to automate the identification of such elements. Moreover, the orthophotomap may show trees which in reality have already been felled, so in any case it is advisable to carry out a physical inspection of the given site.

We consider it relevant to assess tree growth up to a maximum distance of 300 metres from any power line. The closer the tree growth is to a power line, the lower the potential risk of collisions for birds. The value of factor $l_{2}$ is calculated based on the distance from the power line and whether the tree growth is taller than the height of the line:

$$
\begin{aligned}
& \text { If } l_{r}>300 \mathrm{~m} \text {, then } l_{2}=1.0 \\
& \quad \text { otherwise } l_{2}=l_{r} / 300
\end{aligned}
$$

where: $l_{2}=$ factor of proximity of tall tree growth, $l_{r}$ $=$ perpendicular distance of the assessed section of power line from the edge of the vegetation feature reaching higher than the top of the power line.

Electrica 1 distribution 1 in e (criterion $P-$ P o w e r line)

Criterion $P$ is given by the characteristics of the power line itself. From the practical point of view it is convenient if grid company provides the risk assessor with a database (or GIS layer) containing the necessary attributes which form the basis for determining the values of the power line factors for individual sections of line.
Criterion $P$ is calculated as the product of individual factors representing the key features of the power line in question, according to the formula:

$$
P=p_{1} \times p_{2} \times p_{3} \times p_{4}
$$

where: $P=$ criterion of the power line, quantifying the influence of power line characteristics on the degree of risk on the line, $p_{1}=$ factor of power line direction, $p_{2}=$ factor of cable thickness, $p_{3}=$ factor of number of cable levels, $p_{4}=$ factor of number of parallel power lines.

Values of criterion $P$ range between 0 and 1 .

D i r e t i o n of pow e r 1 i n e

The orientation of a power line relative to a water course is one of the key factors increasing the degree of risk on the power line for local and migrating bird species. Power lines proceeding in parallel with a water course represent a distinctly lower risk than those crossing perpendicularly over it (Crowder 2000). The input data for assessing the factor of power line direction are the azimuth of the main direction of the water course and a line vector layer of the power line. The power line is divided into sections from one change in direction to the next, or from one pylon point to the next. The value of factor $p_{1}$ is determined based on the angle of divergence of the power line from the water course as shown in Tab. 6 .

$\mathrm{Th}$ i c kn e s o f c a b l e s

The cables on $22 \mathrm{kV}$ power lines may be carried along in the form of above-ground cable bundles. Sections with this arrangement of cables are considered as problemfree with regard to collisions due to their increased visibility, so the value of $p_{2}$ for this type is 0 . Lines with uninsulated cables of standard thickness have a $p_{2}$ value of 1 . Information about cable thickness should be contained in the attributes table of the database provided by the grid company. For $110 \mathrm{kV}$ lines the factor of cable thickness is not assessed, as its value is automatically set at 1 .

Tab. 6. Values of factor $p_{1}$ depend on the angle of divergence between the azimuths of the assessed power line section and the prevailing direction of main water courses.

Tab. 6. Hodnoty faktora $p_{1} \vee$ závislosti od uhla odklonu azimutov hodnoteného segmentu vedenia voči prevažujúcemu smeru vel'kých vodných tokov.

\begin{tabular}{cc}
\hline $\begin{array}{c}\text { divergence between azimuths of power line and main water courses in the region } / \\
\text { odklon azimutov vedenia a vel'kých tokov v regióne }\end{array}$ & $\begin{array}{c}\text { value of factor } \boldsymbol{p}_{\mathbf{1}} I \\
\text { hodnota faktora } \boldsymbol{p}_{1}\end{array}$ \\
\hline $75.01-90^{\circ}$ & 1.00 \\
$15.01-75^{\circ}$ & 0.95 \\
$>15^{\circ}$ & 0.90 \\
\hline
\end{tabular}


$\mathrm{Numb}$ e r of horizontal le vel s of c a b l e s

Factor $p_{3}$ is determined based on the attributes of the vector layer supplied to the risk assessor by the grid company. The values of factor $p_{3}$ depend on the number of horizontal levels of cables on $22 \mathrm{kV}$ lines as shown in Tab. 7. The greater the number of levels, the better the visibility of the line and the lower the potential risk of collision.

For $110 \mathrm{kV}$ power lines the factor of number of cable levels is not assessed, as its value is automatically set at 1 .

$\mathrm{Numb}$ e r of paralle 1 p o w e r $1 \mathrm{in} \mathrm{e} \mathrm{s}$

The number of power lines running in parallel can be read from the map (or vector layer) of lines provided by the grid company. Values of factor $p_{4}$ depend on the number parallel power lines as shown in Tab. 8 .

Power line sections with low risk of collisions, once the calculations are adjusted and verified, need no further attention paying to them. On the other hand, sections with high and medium risk of collisions on paper need to be attentively inspected in the field, critical sections targeted for finds of birds killed as a result of collisions, their causes analyzed, and measures for their elimination subsequently proposed. These may consist for example in the installation of flight diverter devices (Janss \& Ferrer 1998, Morkill \& Anderson 1991, Yee 2008, Barrientos et al. 2011, 2012, Sporer et al. 2013), laying the power line cables in the ground (APLIC 2012, Raab et al. 2012), or proposing a change in the line's route through the countryside (Haas et al. 2005, D'Amico et al. 2019).

\section{Discussion}

Within the territory of the Slovak Republic alone we have records of almost 35,000 kilometres of transmission and distribution power lines. Not all of these pose a risk of bird collision however, and it not necessary to take measures against collisions along their whole length. For the electricity companies as well, it would be unrealistic from the technical, personnel and above all financial points of view to implement protective measures on such a scale.

One of the possibilities of identifying priority sections for fitting with protective devices lies in the application of the methodology presented above, which makes use of a digital model to apply in practice the available knowledge and key parameters which are put forward in specialist studies as the principal factors influencing the final degree of risk of bird collisions. This methodology also starts out from the data gathered by the LIFE Energy project team and from more than 15 years of experience with issues of bird collisions with power lines within Slovakia (Šmídt et al. 2017).

This methodology was developed for $22 \mathrm{kV}$ and 110 $\mathrm{kV}$ distribution lines. It was applied to a total of 6,235 $\mathrm{km}$ of power lines within the framework of the LIFE Energy project. After application of the methodology and based on the results of field research in the period 12/201-02/2016, flight diverter devices were initially installed on a total of $77 \mathrm{~km}$ of power line sections in the category of greatest degree of risk. Moreover almost $90 \%$ correlation was found between sections with high risk of collisions and numbers of outages involving power installations recorded by the grid companies.

The initial selection of so-called indicated species turned out to be very important. The selected species

Tab. 7. Values of factor $p_{3}$ depending on the number of horizontal levels of cables on the power line.

Tab. 7. Hodnoty faktora $p_{3}$ podl'a počtu horizontálnych úrovní vodičov elektrického vedenia.

\begin{tabular}{cc}
\hline $\begin{array}{c}\text { number of cable levels on } \mathbf{2 2 ~ k V l i n e ~} / \\
\text { počet horizontálnych úrovní vodičov na vedení } \mathbf{2 2 ~ k V}\end{array}$ & $\begin{array}{c}\text { value of factor } \boldsymbol{p}_{3} / \\
\text { hodnota faktora } \boldsymbol{p}_{3}\end{array}$ \\
\hline 1 & 1.00 \\
2 & 0.95 \\
3 and more / a viac & 0.90 \\
\hline
\end{tabular}

Tab. 8. Values of factor $p_{4}$ depending on the number of parallel power lines.

Tab. 8. Hodnoty faktora $p_{4}$ podla počtu paralelných vedení.

\begin{tabular}{cc}
\hline number of parallel line / počet paralelných vedení & value of factor $\boldsymbol{p}_{\mathbf{4}} /$ hodnota faktora $\boldsymbol{p}_{\mathbf{4}}$ \\
\hline 1 & 1.00 \\
2 & 0.95 \\
3 and more / a viac & 0.90 \\
\hline
\end{tabular}


Šmídt J, Hapl E \& Gális M: Methodology of risk assessment for electricity distribution lines in Slovakia with regard to potential bird mortality due to collisions with power lines

Cygnus olor, Ardea cinerea, Nycticorax nycticorax, Ardea alba and Anas platyrhynchos were more frequently killed, and new finds were made at the same sites just a few dozen or at most a few hundred metres apart. These finds both indicated and confirmed to us which sections of power line were risky in terms of bird collisions, because we came to expect higher frequency of collisions with nearby power lines wherever we found concentrated populations of these species in the countryside. The universality and possibility of setting the values of parameters in this methodology (especially the technical variables) enabled the same procedure of calculating the degree of risk of collision to be applied in the case of $400 \mathrm{kV}$ transmission lines as well (data not shown). Through its use, sections of line with high probability of collisions were identified during the preparation phase of planning documentation. Based on our assessments, specific sections were identified and assigned for installation of flight diverter devices on the overland cables as compensation measures with regard to birdlife conservation.

It is possible to find categorization of power lines into various degrees of risk in several foreign studies. They make use of more or less similar approaches, in the sense that they apply parameters quantifying the degree of risk for individual species in order to define those which attract higher risk of collision with power lines. They also apply a selection of criteria (morphological parameters) based on the work by Bevanger (1998). Some of them also utilize factors based on the topography of the assessed area and the type of construction of the power lines. Subsequently these variables are vectorized using GIS tools and then visualized in map form with various scales of resulting degree of risk. The assessment in a Belgian study for example (Derouaux et al. 2012) sets out from the principle of identifying the priority species with regard to risk of collision, then key biotopes and migration routes. These data were subsequently filtered through power line layers and then a system of assigning scores was introduced based on expert evaluation. The output of this method applied in Belgium is a map of risk levels in the regions plotted with a colour gradient from green (areas with low risk of collisions) up to red (areas with most critical potential for collisions). In Spain, D'Amico et al. (2019) for example defined species at risk according to their morphological and behavioural parameters. Based on their distribution in the country a map of socalled hot spots was created, where it was necessary to carry out measures against collisions. In our methodolo- gy we present a different principle according to which we first employ similar input variables, but then supplement them with information about the topography of the landscape and the type of power line construction, and on the basis of their interaction we are able to define not only hot spots, i.e. areas where it is necessary to implement measures against collisions, but also to distinguish precisely between sections and spans of power lines with differing degrees of risk. A similar principle of creating a precise model sorting power lines into categories of risk is also applied in the work by Heck (2007) in the USA. This author starts with an analysis and subsequent superimposing or weighting with parameters corresponding to the biotope composition and type of power line being assessed for risk. The development of any methodology to a certain extent necessarily reflects the particular geographical variety compared to other, even neighbouring countries. This is the result partly of differing species composition and topography and partly of differing structural versions of power lines. For instance the model created for the territory of Spain (D'Amico et al. 2019) was also tested in the conditions of Portugal, whereupon it revealed differences deriving from the partially different species composition and status of birdlife protection in that country as well as different density of the power line network there. In developing the methodology presented here we set out using the same basic procedures as applied in other methods(i.e. including factors such as mutual positioning of power lines, sites with concentrations of birds, or their migration routes), but we also calculate in the impacts of power line direction relative to the expected prevailing directions of bird movement, slope distribution in the terrain and the presence of tall tree growth. These additionally assessed inputs significantly shorten the resulting lengths of power lines sections which are ultimately assessed as representing some degree of risk, since the real degree of risk is restricted by factors of landscape (slope and vegetation) or the parameters of the power lines themselves.

With increasing worldwide expert knowledge of issues of bird collisions with distribution and transmission power lines, it is possible to improve the appropriacy of values of input variables and their weighting in the modelling process. Identification of risky power line sections and targeted application of available and effective measures (e.g. installation of diverting devices, or changes in power line routing and configuration) in the places with the highest degree of risk is a more effective way in terms of time, technology and financial cost of 
dealing with collisions of birds with power lines, not only on the existing electricity grid but also preventively with regard to newly-planned routes. This is particularly important in the context of the constant growth in extent and density of the power grid in proximity to or passing directly through sites with prevalence of critically endangered species.

We have proposed a method enabling the identification of risky power line sections where there is the highest probability of bird collisions. This method may also be applied in areas with different geographical conditions wherever there is information available about key and potential key bird sites, their species composition and the power lines present in the assessed area. If this method is to be applied for the first time in a particular area, we recommend supplementing it with field observations, especially on sections of power line where a discrepancy appears between the results of categorization and recorded finds of bird mortality. This will help to identify cases of incorrectly evaluated factors, enabling them to be adjusted and the model to be tuned so as to reflect as accurately as possible the degree of risk posed to birds by power lines, and at the same time ensure the easy application of the model in practice.

\section{References}

Alonso JA \& Alonso JC 1999: Collision of birds with overhead transmission lines in Spain, 57-82. In: Ferrer M \& Janns GF (eds), Birds and power lines: collision, electrocution, and breeding. Quercus, Madrid.

Andriushchenko YA \& Popenko VM 2012. Birds and power lines in steppe Crimea: positive and negative impacts. Ukraine. Raptors Conservation 24: 34-41.

APLIC (Avian Power Line Interaction Committee) 1994: Mitigating Bird Collisions With Power Lines: the state of the art in 1994. Edison Electric Institute, Washington, D.C.

APLIC (Avian Power Line Interaction Committee) 2012: Reducing Avian Collisions with Power Lines: The State of the Art in 2012: Edison Electric Institute and APLIC. Washington, D.C.

Barrientos R, Alonso JC, Ponce C \& Palacín C 2011: Meta-Analysis of the Effectiveness of Marked Wire in Reducing Avian Collisions with Power Lines. Conservation Biology 25 (5): 893-903. DOI: 10.1111/j.1523-1739.2011.01699.x.

Barrientos R, Ponce C, Palacín C, Martín CA, Martín B \& Alonso JC 2012: Wire marking results in a small but significant reduction in avian mortality at power lines: A BACI designed study. PLoS ONE 7(3): e32569. DOI:10.1371/journal.pone.0032569

Bernardino J, Bevanger K, Barrientos R, Dwyer J, Marques A, Martin R, Shaw J, Silva J \& Moreira F 2018: Bird collisions with power lines: State of the art and priority areas for research. Biological Conservation 222: 1-13. DOI: 10.1016/j.biocon. 2018.02.029.

Bevanger K 1994: Bird interactions with utility structures: collision and electrocution, causes and mitigating measures. Ibis 136: 412-425.

Bevanger K 1998: Biological and conservation aspects of bird mortality caused by electricity power lines: a review. Biological Conservation 86: 67-76. DOI: 10.1016/S0006-3207(97)00176-6.

Bevanger K \& Brøseth H 2004: Impact of power lines on bird mortality in a subalpine area. Animal Biodiversity and Conservation 27: 67-77.

Crowder MR 2000: Assessment of devices designed to lower the incidence of avian power line strikes. $\mathrm{PhD}$ Thesis, Purdue University, West Lafayete, Indiana.

D'Amico M, Martins RC, Álvarez-Martínez JM, Porto M, Barrientos R \& Moreira F 2019: Bird collisions with power lines: Prioritizing species and areas by estimating potential population-level impacts. Diversity and Distribution 25: 975-982. DOI: 10.1111/ddi.12903.

Derouaux A, Everaert J, Brackx N, Driessens G, Martin GA \& Paquet JY 2012: Reducing bird mortality caused by high- and very-high-voltage power lines in Belgium, final report, Elia and Aves-Natagora. Retrieved October 15, 2019, from https:// www.aves.be/fileadmin/Aves/Colloque50ans/ Bird_and_Powerlines_Aves_Final_Report_2012.pdf.

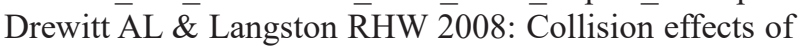
wind-power generators and other obstacles on birds. Annals of the New York Academy of Sciences 1134: 233-266. DOI: 10.1196/annals.1439.015.

Erickson WP, Johnson GD \& Young DPJ 2005: A summary and comparison of bird mortality from anthropogenic causes with an emphasis on collisions, 1029-1042. In: Ralph CJ \& Rich TD (eds): Bird Conservation Implementation and Integration in the Americas: Proceedings of the Third International Partners in Flight Conference. 2002 March 2024; Asilomar, California, Volume 2 Gen. Tech. Rep. PSWGTR191. U.S. Dept. of Agriculture, Forest Service, Pacific Southwest Research Station, Albany, CA. 
Šmídt J, Hapl E \& Gális M: Methodology of risk assessment for electricity distribution lines in Slovakia with regard to potential bird mortality due to collisions with power lines

Gális M, Deutschová L, Šmídt J, Hapl E \& Chavko J 2016: Vysoká cena za pohodlie alebo rizikovost' elektrických vedení pre vol’ne žijúce druhy vtákov [The high price of human comfort or the riskiness of power line for bird species], 77-79. In: Krumpalová Z, Zigová M \& Tulis F (eds), Zborník príspevkov z vedeckého kongresu "Zoológia 2016 " [Proceeding from the science congress "Zoology 2016"]. Constantine the Philosopher University in Nitra, Nitra. [In Slovak with English Summary]

Haas D, Nipkow M, Fiedler G, Scheneider R, Haas W \& Schürenberg B 2005: Protecting birds on powerlines. Nature and Environment No. 140. Council of Europe Publishing, Strasbourg Cedex.

Heck N 2007: A landscape-scale model to predict the risk of bird collisions with electric power transmission lines in Alberta (Unpublished master's thesis). University of Calgary, Calgary. DOI: 10.11575/PRISM/1482.

Janss GFE \& Ferrer M 1998: Rate of bird collision with power lines: effects of conductor-marking and static wire-marking. Journal of Field Ornithology 69 (1): 817.

Janss GFE 2000: Avian mortality from power lines: a morphologic approach of a species-specific mortality. Biological Conservation 95: 353-359. DOI: 10.1016/S0006-3207(00)00021-5.

Janss GFE \& Ferrer M 2000: Common crane and great bustard collision with power lines: collision rate and risk exposure. Wildlife Society Bulletin 28 (3): 675680. DOI: $10.2307 / 3783619$.

Jenkins AR, Smallie JJ \& Diamond M 2010: Avian collisions with power lines: a global review of causes and mitigation with a South African perspective. Bird Conservation International 20: 263278. DOI: $10.1017 / \mathrm{S} 0959270910000122$.

Martin GR \& Shaw JM 2010: Bird collisions with power lines: failing to see the way ahead? Biological Conservation 143: 2695-2702. DOI: 10.1016/ j.biocon.2010.07.014.

Martin GR 2011: Understanding bird collisions with man-made objects: A sensory ecology approach. Ibis 153: 239-254. DOI: 10.1111/j.1474-919X. 2011.01117.x.

Morkill AE \& Anderson SH 1991: Effectiveness of marking powerlines to reduce sandhill crane collisions. Wildlife Society Bulletin 19: 442-449.

Murphy RK, McPherron SM, Wright GD \& Serbousek
KL 2009: Effectiveness of avian collision averters in preventing migratory bird mortality from powerline strikes in the central Platte River, Nebraska. Grand Island, Nebraska.

Quinn M, Alexander S, Heck N \& Chernoff G 2011: Identification of bird collision hotspots along transmission power lines Alberta: an expert-based Geographic Information System (GIS) approach. Journal of Environmental Informatics 18: 12-21. DOI: $10.3808 /$ jei.201100194.

Raab R, Schütz C, Spakovszky P, Julius E \& Schulze $\mathrm{CH}$ 2012: Underground cabling and marking of power lines: conservation measures rapidly reduced mortality of West Pannonian great bustards Otis tarda. Bird Conservation Interational 22: 299-306. DOI: $10.1017 / \mathrm{S} 0959270911000463$.

Rubolini D, Gustin M, Bogliani G \& Garavaglia R 2005: Birds and powerlines in Italy: An assessment. Bird Conservation International 15: 131-145. DOI: 10.1017/ S0959270905000109.

Shaw JM, Jenkins AR, Smallie JJ \& Ryan PG 2010: Modelling powerline collision risk for the Blue Crane Anthropoides paradiseus in South Africa. Ibis, 152(3): 590-599. DOI: 10.1111/j.1474-919X. 2010.01039.x.

Shobrak M 2012: Electrocution and collision of birds with power lines in Saudi Arabia. Zoology in the Middle East 57: 45-52. DOI: 10.1080/ 09397140.2012 .10648962$.

Silva JP, Palmeirim JM, Alcazar R, Correia R, Delgado A \& Moreira F 2014: A spatially explicit approach to assess the collision risk between birds and overhead power lines: a case study with the little bustard. Biological Conservation 170: 256-263. DOI: 10.1016/j.biocon.2013.12.026.

Sporer MK, Dwyer JF, Gerber BD, Harness RE \& Pandey AK 2013: Marking power lines to reduce avian collisions near the Audubon National Wildlife Refuge, North Dakota. Wildlife Society Bulletin 37: 796-804. DOI: 10.1002/wsb.329.

Šmídt J, Hapl E \& Gális M 2017: Hodnotenie rizikovosti elektrických vedení v Slovenskej republike $\mathrm{z}$ pohl'adu možného úhynu vtákov spôsobeného nárazom do vedenia [Evaluation of riskiness of electric power lines from the viewpoint of bird deaths caused by collision with power lines in Slovakia], 202. In: Bryja J, Horsák M, Horsáková V, Řehák Z \& Zukal J (eds): Zoologické dny Brno. 
Sborník abstraktů z konference [Zoological Days. Proceedings abstracts from conference]. Institute of Vertebrate Biology Czech Academy of Sciences, Brno. [In Slovak]

Yee ML 2008: Testing the Effectiveness of an Avian
Flight Diverter for Reducing Avian Collisions with Distribution Power Lines in the Sacramento Valley, California. California Energy Commission, PIER Energy-Related Environmental Research Program. CEC-500-2007-122. 